UDC 347.4

DOI https://doi.org/10.32849/2663-5313/2021.7.01

Yuriy Opanashchuk,

External Postgraduate Student, F. G. Burchak "Scientific Research Institute of Private Law and Business of Nationality Academy of Law Sciences of Ukraine”, 23-a, Raierskoho street, Kyiv, Ukraine, postal code 01042

ORCID: orcid.org/0000-0003-3381-9410

Opanashchuk, Yuriy (2021). Consequences of non-compliance with the requirements for notarization of transactions concluded by one of the spouses. Entrepreneurship, Economy and Law, 7, 5-10.

\title{
CONSEQUENCES OF NON-COMPLIANCE WITH THE REQUIREMENTS FOR NOTARIZATION OF TRANSACTIONS CONCLUDED BY ONE OF THE SPOUSES
}

\begin{abstract}
Domestic economic, social, and political reforms of recent decades have been designed to transform the available system of social relations qualitatively, including proper regulation of the conclusion of the transactions that require notarization, specifically of ones that are concluded by one of the family members. The purpose of the article is to conduct a comprehensive analysis of the key controversial or inconsistent aspects of the legal regulation of notarization of transactions concluded by one of the spouses. The methodology of the research is based on the system of general scientific and specialized legal methods. In particular, the author has applied systems analysis, synthesis, deduction, induction, generalization, comparative-legal method, and formal-legal approach. Results. Research findings involve a novel approach to determine the ways to overcome incoherence amidst the complexity of the institution under consideration, which seamlessly encompasses the elements of civil and matrimonial nature; therefore, it should be concurrently regulated by the rules of civil and family law of our state. Conclusions. The results of this study indicate the relevance of a proposal to reverse the situation in which a marriage contract certified by a notary before the formal marriage does not enter into force de jure but leads to the emergence, change, or termination of the property rights to certain assets of the other spouse. The author believes that the mentioned legal collapse can be optimized by granting a marriage contract legal force from the moment of its notarization regardless of the official registration of marriage. In the author's profound conviction, which has been substantiated in this study, it is the above approach that can assist in resolving longstanding legislative controversy and simplifying the procedure for ensuing civil law consequences for the conclusion of transactions, which are not certified by a notary, by one of the spouses, even if they are in a de facto marriage.
\end{abstract}

Key words: notarial system, transaction, contract, spouses, notarization.

\section{Introduction}

More than thirty years ago, our state embarked on a path of comprehensive reforms in the structure and essence of the entire social relations; therefore, modern Ukraine keeps its smooth progress, the vector of which is set by the focus on generally recognized principles and regulations of international legislation. In this context, the institution of family and marriage, which is one of the most conservative by its nature and doesn't tolerate novelties due to deeply-rooted superstitious beliefs and local traditions of particular regions, was also subject to alterations both in implementation and legal regulation.
The abovementioned fact is distinctively illustrated by matrimonial relations regulating particularities of the notarization of transactions of one of the spouses, even if relations are not formalized.

Keeping in mind the age-long past of the relations under consideration, one can assert their systemically important nature confirmed by the centuries-old genesis of matrimonial relations, which had been originally controlled by customs and, over time, shaped the system of legal regulation at the level of codified law branch. However, despite the massive extension, law enforcement practice in the property relations of spouses 
shows that many issues are handled casually; this sort of situation needs an immediate engagement of the consolidated efforts of theorists and legal practitioners.

Analysis of recent research and publications. The contributions of domestic scientists give favorable consideration to the legal institution under analysis, which is one of the most important in the science of civil law. Over the years, individual aspects of the notarization of transactions concluded by one of the spouses were examined by T. V. Bodnar, N. D. Vintoniak, N. Ya. Diachkova, S. Kozlov, I. M. Percheklii, Yu. O. Pylypenko, V. M. Solovetska, F. A. Turchyn, T. Ye. Kharytonova, V. V. Sharovarova. At the same time, a great deal of the scientific publications devoted to the specific area doesn't depreciate the relevance of this paper because many theoretical and practical issues are still controversial since legal doctrine is in its infancy that affects statutory regulation of particular relations. The mentioned gaps have established the logic of the material statement in this article that allows grading from the most common problems to the most complicated and inconsistent ones.

The purpose of the research involves conducting a comprehensive analysis of the core controversial or inconsistent aspects of legal regulation of the notarization of transactions concluded by one of the spouses. The author has formulated and gradually performed the following scientific research tasks to achieve the outlined purpose:

- to analyze and elucidate fundamental statutory provisions regulating civil law consequences of non-implementation of notarization of transactions concluded by one of the spouses, who are in registered or de facto marriage;

- to determine the point of acquisition of the rights and obligations under the marriage contract signed before marriage registration to clarify primary effects of non-compliance with notarization of transactions concluded by one of the spouses;

- to define features of notarization of transactions concluded by de facto spouses.

Statement of basic research material. The critical importance of the issues under study is once more reinforced by the fact that some transactions, which at first glance are not associated with matrimonial legal relations, shall be certified by a notary given the necessity to observe and protect the interests of other family members. In particular, to certify transactions arising from marital relations of the families, which have kids or minor children (Banasevych et al., 2021). In T. Ye. Kharytonova's opinion, which the author completely shares, the beforementioned practice is an additional guarantee for protecting the property rights of the youngest and least protected family members (Kharytonova, 2018, p. 58). The above is also peculiar to corporate relations. Thus, when certifying a share purchase agreement in the charter capital of a company, a notary checks for spousal consent in case of share acquisition using assets of joint tenancy to identify the property's legal status. As V. I. Krat and M. O. Bozhok rightly note, if one of the spouses gains a share in the charter capital of the company, a notary requires spousal consent to purchase using joint financial resources (Krat, Bozhok, 2017 , pp. 4-10). On the other hand, an agreement on the alienation of corporate rights by one of the spouses shall also be certified by a notary; however, as N. D. Vintoniak accurately states, the legislator doesn't provide for the relevant individual rule. In the scientist's opinion, in case of notarization of an agreement on the alienation of corporate rights, the spouse who will act as an acquiring party under the agreement based on joint matrimonial property shall get a spousal consent form certified by a notary (Vintoniak, 2019, p. 45).

Even a last will and testament as a unilateral transaction made by one of the spouses requires more focused attention at the moment of notarization than other similar legal relations. According to Yu. O. Zaika's conclusions, the last will form is subject to more strict requirements than other civil law transactions: the last will as a transaction comes into effect after the party's death (Zaika, 2004, p. 73).

\section{Statutory regulation}

In the context of statutory regulation of the issues under study, para. 4.2, Chapter 1, Section II of the Order of the Ministry of Justice of Ukraine № 296/5 as of 22.02.2012 "On the Approval of the Procedure for Performing Notarial Acts by Notaries of Ukraine" (hereinafter referred to as "Procedure") asserts that when certifying transactions in the disposal of community property, a notary requires a written spousal consent if a document verifying the proprietary right was issued in the name of one ofthespouses(Poriadokvchunennianotarialnykh dij, 2017).

The analysis of the rules of art. 65 of the Family Code of Ukraine (the FC of Ukraine) demonstrates that the legislator specified the types of transactions that prescribe spousal consent: a transaction that is beyond petty daily one; transactions related to valuable objects; transactions requiring notarization and (or) public registration. Theorists extended this list by 
including a set of related and interconnected legal relations, e. g. corporate. In the words of N. D. Vintoniak, in case of contributing corporate property to a legal entity's charter capital by one of the spouses as an investment during the registration of a corporation, it is believed that objects of community property are transferred to the charter capital by mutual agreement of spouses. In other words, there is a presumption of spousal consent. Any actions of one of the spouses towards the disposal of joint tenancy means from the date of marriage registration are considered to be committed with the consent of the other spouse, including the deposit of joint tenancy means as an investment in the corporate's charter capital (Vintoniak, 2019, p. 45).

At the same time, a transaction related to property disposal can be certified by a notary without spousal consent in the following cases:

- a wife/a husband possesses separate property (article 57 of the Code); according to sub-para. 4.5, para. 4, chapter 1 of Section II of the Procedure of Facts' Checking, a notary makes a note in a transaction copy, which is attached to the files of the notarial case, with reference to requisites of specific documents if the documents are not attached to the transaction copy;

- a transferor - unmarried woman/man, widow/widower; according to sub-para. 4.6, para. 4, Chapter 1 of Section II of the Procedure, when a notary certifies transactions in property alienation on behalf of an unmarried person (unmarried woman/man, widow/widower), a transferor files an application saying that property that is the subject matter of this transaction is not joint tenancy. The notary discloses the application to the other party under the transaction and mentions this fact throughout the text. The transferer shall personally submit such an application; in case of conducting a transaction by proxy, a representative does the above if the transferor has authorized him/her to file the application confirming his/her (transferor's) private ownership on behalf of the transferor;

- property acquired by either spouse when living apart from his/her spouse due to the de facto termination of a marriage. To confirm that property was acquired by either spouse when living apart from the other due to the de facto termination of a marriage, one shall provide a copy of the effective court decision recognizing private ownership of one of the spouses that is the subject matter of the agreement (sub-para. 4.7, para. 4, Chapter 1 of Section II of the Procedure).

Thus, according to para. 2, art. 65 of the FC of Ukraine, a failure to provide consent by one of the spouses is the sole reason to hold a transaction invalid. As T. V. Bodnar generalizes, a lack of spousal consent should be considered as the sole reason to hold the agreement on property disposal, that is joint tenancy, concluded by one of the spouses invalid (Bodnar, 2017, p. 81). Moreover, the author shares N. D. Vintoniak's opinion that receipt of a notarized form of spousal consent to enter into agreements verifies that the agreement is to be concluded upon spousal consent, and each of them is informed about the transfer of joint property to corporate charter capital. Receipt of a notarized spousal notice form is the guarantee for reducing the practice of declaring such agreements invalid through judicial procedures (Vintoniak, 2019, pp. 45-46). Other scientists develop these suggestions. Thus, N. Ya. Diachkova and F. A. Turchyn mark that a notice giving consent is a mere juridical fact which doesn't result in creating new rights and obligations of neither party. In this scenario, joint tenancy is regarded as an inseparable item, and a joint-tenant gives his/her consent to alienate a share of proprietary interest in the whole item (Diachkova, Turchyn, 2015, p. 163).

Moreover, legitimacy of such a transaction can be adjudicated, and thus, according to V. M. Solovetska, judgment is a document certifying the origin under certain circumstances of the ownership right of community property which was the separate property of a wife, a husband. For instance, in practice, there are situations when the separate property of one of the spouses keeps its value, or its cost essentially boosts due to the very joint endeavors of both spouses (Solovetska, 2014, pp. 51-52).

3. A point of the origin of rights and obligations under a marriage contract concluded before marriage registration

The fundamental problem discussed by scientists and practitioners in the context of the issue under study is the origin of rights and obligations under a marriage contract, which an engaged couple concludes and gets it notarized BEFORE (the author's notes) the official registration of a marriage. According to para. 1, art. 95 of the FC of Ukraine, if a marriage contract is concluded before marriage registration, it goes into effect on the day of marriage registration, i. e. the contract isn't effective before marriage registration. Therefore, para. 3, art. 334 of the Civil Code of Ukraine mandatorily enshrines that the acquirer gains the ownership right by the contract, that is subject to notarization, since the moment of such notarization. 
However, the FC of Ukraine doesn't include any special rules which specify the moment of acquisition of the proprietary right under the spousal agreement. Consequently, there is a long-standing situation, which hasn't long changed at the legislative level, when a notarized marriage contract concluded before marriage registration (pursuant to the FC of Ukraine) doesn't go into effect but results in the acquisition of the property right by one of the spouses (pursuant to the Civil Code of Ukraine). It stands to reason that the mentioned controversy must be eliminated. To handle the situation, V. V. Sharovarova proposes to enshrine a more flexible rule in para. 3, art. 334 of the Civil Code of Ukraine: the title to the property under a contract subject to notarization shall arise since the moment of such notarization, unless otherwise provided by law (Sharovarova, 2017, pp. 122-123). There is an obvious need to qualitatively update the text of current civil laws regulating relations under study through improving the basic approaches to understanding and implementation of challenging areas concerning the non-compliance with the requirements of notarization of transactions concluded by one of the spouses. It is noteworthy that many prominent scientists of our state support the necessity to optimize prevailing civil acts. In particular, S. O. Pohribnyi and O. O. Kot stress that the specification of priority directions for improving civil laws should ensure the most decisive answers to current demands of lawenforcement practice, which the most recent edition of civil legislation lacks (Pohribnyi, Kot, 2021, p. 113).

At the same time, S. A. Kozlov proposes to update the Civil Code of Ukraine with a special rule: under a marriage contract concluded before marriage registration, the right of ownership doesn't arise since notarization but since marriage registration and entry of a marriage contract into force (Kozlov, 2007). This proposal doesn't contradict the proposal supported by the author but enhances it and adds complexity and consistency of legal influence on relations under study.

Moreover, the potential way out comprises the conclusion of a marriage contract that permits de jure or future spouses to specify expectations about the marriage, outline the character of their future relationships and interaction with others, a circle of contacts, predominant activities, etc. As V. V. Sharovarova generalizes, such provisions are included in a marriage contract to motivate the proper behavior of spouses within marriage, not their compulsory execution in the future (Sharovarova, 2017, p. 123).
4. Notarization of the transactions of persons who are in a de facto marriage

The moment of concluding a transaction, which requires notarization, by persons who have a de facto relationship deserves to be highlighted. On the one hand, the institution of de facto marital relations has been functioning in domestic legislation for almost 20 years (since 2004); however, formally specified relationships are beyond the legal pale that is unacceptable because laws shall consider social trends and keep up-to-date, especially when a blanket prevalence of de facto relationship needs enhanced protection of all parties involved. Moreover, case law of using art. 74 of the FC of Ukraine demonstrates ambiguousness of approaches to settle disputes resulting from the mentioned category of legal relations. In particular, this article of the FC of Ukraine stipulates that whenever a woman and a man live together as an unmarried couple, the property they acquired while living together belongs to them as community property unless otherwise provided by their written agreement. This property is covered by the provisions of the Family Code of Ukraine (namely Chapter 8 of the Family Code of Ukraine "Right of spouses to marital property"). In the view of $\mathrm{Yu}$. O. Pylypenko, the above conveys that compared to a registered marriage in which the title to property acquired within marriage emerges automatically (by law) and joint tenancy of de facto spouses emerges either as a result of the agreement's conclusion or due to the judgment on the recognition of property acquired while living together as joint tenancy - subsequently, the provisions of Chapter 8 of the FC of Ukraine can be applied to that sort of property (Pylypenko, 2015, p. 195)

De facto marital relations undoubtedly should be regarded as a complex institution regulated by the rules of family and civil law. Therefore, statutory regulation of all circumstances related to the relevant social phenomenon also should be exercised through a harmonious engagement of mutually reinforcing rules of both law branches.

\section{Conclusions}

Summarizing the abovementioned, the author considers it necessary to stress that the family and marital relationships are a mutually agreed system of social factors which crucially determine the state of society and prospect for its progressive development, continuity of generations, and legal protection of every individual. This is explained by the fact that the status of modern families is both an outcome and trigger of many processes currently taking place in society. Every family 
undergoes a strong influence of all active factors of social dynamics and simultaneously produces these determinants. However, it is possible to implement extensive human-centric capacity peculiar to all property relations which arise from marital and family relations upon the condition of adequate statutory regulation of all spheres of legal relations between the members of one family and involving the third parties when concluding transactions which shall be notarized.

Given the complexity of the institution under study that smoothly encompasses the elements of civil and marriage-family nature, the author ascertains it should be concurrently regulated by the rules of civil and family laws of our state, which a priori can't contradict each other. Consequently, it is worth reversing the situation in which a marriage contract certified by a notary before the formal marriage does not enter into force de jure but leads to the emergence, change, or termination of property rights to certain assets of the other spouse. The author believes that the mentioned legal collapse can be optimized by granting a marriage contract legal force from the moment of its notarization regardless of the official registration of marriage. In the author's profound conviction, which has been substantiated in the present study, it is the above approach that can assist in resolving longstanding legislative controversy and simplifying the procedure for ensuing civil law consequences for the conclusion of transactions, which are not certified by a notary, by one of the spouses, even if they are in de facto marriage.

\section{References:}

Banasevych, I.I., Heints, R.M., Lohvinova, M.V., Oliinyk, O.S. (2021). Osoblyvosti pravovoho stanovyshcha subiektiv tsyvilnoho prava [Features of the legal status of subjects of civil law]. Journal of the National Academy of Legal Sciences of Ukraine, issue 28, no. 2 (in Ukrainian).

Bodnar, T.V. (2017). Vidsutnist zghody yak pidstava vyznannia pravochyniv nediisnymy u simeinomu pravi Ukrainy [Lack of consent as a ground for invalidating transactions in family law of Ukraine]. Problemy tsyvilnoho prava ta protsesu: tezy dop. Uchasnykiv nauk.-prakt. konf., prysviach. cvitlii pamiati O.A. Pushkina, 19-20 trav. Kharkiv: KhNUVS (in Ukrainian).

Diachkova, N.Ya., Turchyn, F.A. (2015). Zghoda odnoho z podruzhzhia na vchynennia pravochyniv shchodo spilnoho maina [Consent of one of the spouses to enter into transactions for joint property]. Pravo $i$ bezpeka, no. 2(57) (in Ukrainian).

Kharytonova, T.Ye., Percheklii, I.M. (2018). Osoblyvosti notarialnoho posvidchennia pravochyniv za uchastiu malolitnikh ta nepovnolitnikh ditei [Features of notarization of transactions involving minors and minor children]. Chasopys tsyvilistyky, no. 29 (in Ukrainian).

Kozlov, S. (2007). Shliubnyi dohovir: prahmatyzm chy neobkhidnist [Marriage contract: pragmatism or necessity]. Pravovyi tyzhden: Yurydychna hazeta, no. 48(69). Retrieved from: http://www.yur-gazeta.com/ oarticle/1425 (in Ukrainian).

Krat, V.I., Bozhok, M.O. (2017). Metodychni rekomendatsii shchodo posvidchennia dohovoriv kupivli-prodazhu chastky v statutnomu kapitali tovarystva $\mathrm{z}$ obmezhenoiu vidpovidalnistiu [Methodical recommendations on certification of purchase and sale agreements of shares in the authorized capital of a limited liability company]. Kyiv: Notarialna palata Ukrainy (in Ukrainian).

Pohribnyi, S.O., Kot, O.O. (2021). Onovlennia Tsyvilnoho kodeksu Ukrainy yak zaporuka efektyvnoi vzaiemodii derzhavy ta suspilstva [Updating the Civil Code of Ukraine as a guarantee of effective interaction between the state and society]. Journal of the National Academy of Legal Sciences of Ukraine, issue 28, no. 1 (in Ukrainian).

Pro zatverdzhennia poriadku vchynennia notarialnykh dii notariusamy Ukrainy [About the statement of the order of commission of notarial actions by notaries of Ukraine], Nakaz Ministerstva yustytsii Ukrainy № 296/5 vid 22.02.2012. Retrieved from: https://zakon.rada.gov.ua/laws/show/z0282-12\#Text (in Ukrainian).

Pylypenko, Yu.O. (2015). Shchodo praktyky ukladannia dohovoriv ipoteky faktychnym podruzhzhiam [Regarding the practice of concluding mortgage agreements with de facto spouses]. Piati yurydychni dysputy pamiati Ye. V. Vaskozskoho (in Ukrainian).

Simeinyi kodeks Ukrainy [Family Code of Ukraine], Zakon № 2947-III vid 10.01.2002. Retrieved from: https://zakon.rada.gov.ua/laws/show/2947-14\#Text (in Ukrainian).

Solovetska, V.M. (2014). Posvidchennia pravochyniv shchodo rozporiadzhennia mainom, yake ye spilnoiu sumisnoiu vlasnistiu podruzhzhia [Certificate of transactions for the disposal of property that is the joint property of the spouses]. Biuleten Ministerstva yustytsii Ukrainy (in Ukrainian).

Sharovarova, V.V. (2017). Osoblyvosti notarialnoho posvidchennia shliubnoho dohovoru v Ukraini [Features of notarization of marriage contract in Ukraine]. Pravova derzhava, no. 26 (in Ukrainian).

Vintoniak, N.D. (2019). Nabuttia korporatyvnykh prav odnym iz podruzhzhia [Acquisition of corporate rights by one of the spouses]. Chasopys tsyvilistyky, issue 33 (in Ukrainian).

Zaika, Yu.O. (2004). Forma zapovitu yak umova yoho diisnosti [The form of the will as a condition of its validity]. Visnyk Khmelnytskoho instytutu rehionalnoho upravlinnia ta prava, no. 1-2 (in Ukrainian). 


\section{Юрій Опанащук,}

здобувач, Науково-дослідний інститут приватного права і підприємниитва імені академіка Ф. Г. Бурчака Національної академії правових наук Украйни, вул. М. Раєвського, 23-а, Київ, Україна, індекс 01042, у_орапаshchuk@ukr.net

ORCID: orcid.org/0000-0003-3381-9410

\section{НАСЛІДКИ НЕДОТРИМАННЯ ВИМОГ НОТАРІАЛЬНОГО ПОСВІДЧЕННЯ ПРАВОЧИНІВ, УКЛАДЕНИХ ОДНИМ ІЗ ПОДРУЖЖЯ}

Анотація. Економічні, соціальні та політичні реформи останніх десятиліть у нашій країні покликані якісно трансформувати наявну систему суспільних відносин, що охоплюе й належну регламентацію вчинення правочинів, які потребують нотаріального посвідчення, а особливо тих із них, котрі укладаються одним із членів сім'ї. Мета дослідження полягає в тому, щоб здійснити всебічний аналіз основних суперечливих чи неузгоджених аспектів правового регулювання питань нотаріального посвідчення правочинів, укладених одним із подружжя. Методологічна основа дослідження грунтується на системі загальнонаукових і спеціально-юридичних методів. Зокрема, використані методи системного аналізу, синтезу, дедукції, індукції, узагальнення, порівняльноправовий метод, формально-юридичний метод. Результати. У підсумку проведеного дослідження вперше сформульовано підхід до окреслення шляхів подолання неузгодженості в контексті саме комплексності досліджуваного інституту, що органічно поєднує в собі елементи цивільно-правового та шлюбно-сімейного характеру, а тому має паралельно регламентуватися нормами як цивільного, так і сімейного законодавства нашої держави. Висновки. Як результати проведеного дослідження варто виділити пропозицію кардинально змінити ситуацію, за якої шлюбний договір, посвідчений нотаріусом до офіційного укладення шлюбу, формально не набуває чинності, проте призводить до виникнення, зміни чи припинення права власності на певні види майна в іншого 3 подружжя. На нашу думку, оптимізувати цей правовий колапс можна лише шляхом надання юридичної сили такому шлюбному договору з моменту нотаріального посвідчення незалежно від факту офіційної реєстрації шлюбу. У представленому дослідженні аргументовано обгрунтовано, що саме такий підхід спроможний нарешті подолати багаторічну законодавчу колізію та спростити саму процедуру настання цивільно-правових наслідків щодо вчинення нотаріально непосвідчених правочинів одним із подружжя, навіть якщо вони перебувають у фактичних шлюбних відносинах.

Ключові слова: нотаріат, правочин, договір, подружжя, нотаріальне посвідчення.

The article was submitted 05.07.2021

The article was revised 28.07.2021

The article was accepted 18.08.2021 